\title{
Juniperus communis L. at the southern limit of its distribution in Eastern Polesie
}

\author{
Oleksandr Lukash*, Petro Buzunko, Svitlana Kyriienko, Alina Sliuta
}
Department of Ecology and Nature Conservation, T. Shevchenko National Pedagogical University of Chernihiv, Hetman Polubotko Str., 53, 14013 Chernihiv, Ukraine,
*e-mail: lukash2011@ukr.net

Received: 16 March 2017/Accepted: 02 June 2017

\begin{abstract}
The authors investigated the occurrence of Juniperus communis in different vegetation syntaxa at the southern limit of its distribution in Eastern Polesie: pine forest communities representing the associations Peucedano-Pinetum W. Mat. (1962) 1973, Cladonio-Pinetum Juraszek 1927, Veronico incanae-Pinetum Bulokhov et Solomeshch and oak-pine forests - the Querco-Pinetum association (W. Matuszkiewicz 1981) J. Matuszkiewicz 1988.

New localities of $J$. communis were found for the first time in Eastern Polesie. The largest populations of the species (in terms of area covered and the number of individuals) in Eastern Polesie occur in the territory of Ukraine (Pridesnyansky physical-geographic region) and Russia (Nerusso-Desnyansky and Snovsky physical-geographic regions). In Eastern Polesie, the population of the species occupies the largest area (22 ha) in the Klimovo forest district (Bryansk region, Russia), and is characterised by the dynamic equilibrium between the death and replacement of individuals.

The southern limit (in Eastern Polesie) of the distribution of communities with $J$. communis codominance was established in the course of the study. It passes through the villages Brahlov-Razlyoty-Ochkino-Navlya. J. communis occurs sporadically south of the distribution limit and shows signs of climate impact: seedlings and juvenile plants are absent, while reproductive individuals are characterised by very low seed production.
\end{abstract}

Key words: Juniperus communis L., pine forests, syntaxa, population, distribution.

\section{Introduction}

In Russia, the boreal and submeridional circumpolar species Juniperus communis L. is common in coniferous and mountain forests of the European part, Siberia and the Caucasus (Valyagina-Malyutina, 2001). The species is fairly common in the northern regions of Central Russia and sporadic in the south. In Ukraine, the species occurs at the southern limit of its distribution - it sporadically spreads in the forest zone, the Carpathians and rarely in forest steppes (Didukh et al., 2000). On the left bank of the Dnieper River, J. communis is found over a very limited area - growing on pine forest terraces of the Desna and the Dnieper rivers. Ipso facto, it is included in the Red Book of the Bryansk region (Fedorov, 2004), the lists of regionally rare spe- cies of vascular plants in Chernihiv and Sumy regions in Ukraine. Mulyarchuk (1962) reported on the occurrence of J. communis in Eastern Polesie in Ukraine. Eastern Polesie, which covers left-bank territories of the Dnieper in Russia, Belarus and Ukraine (Marinich, 1963), is interesting in terms of clarifying the limits of the $J$. communis continuous range. No attention has been paid so far to the occurrence of Juniperus communis in different syntaxa in the region or the population structure of the species. It was therefore interesting, from a scientific and practical point of view, to investigate plant communities with $J$. communis in order to study the population structure of the species at different sites, as well as to determine the extension of the southern distribution limit of plant communities with J. communis codominance in Eastern Polesie. 


\section{Study area}

Eastern Polesie is part of the European sandy low plains woodlands located in the latitudinal direction. The total area of Eastern Polesie is about 3.25 million ha. It is located in the Gomel region (Belarus), the Bryansk region (Russia), the Chernihiv region and the Sumy region (Ukraine).

The eastern subprovince of the Polesie geobotanical province, which occupies the left bank of the Dnieper in Belarus, Russia and Ukraine, has more continental and less humid climate compared to the northern and southern subprovinces (Marinich, 1963).

The average annual air temperature is $+5.5^{\circ} \mathrm{C}$, the average air temperature of January is $-7^{\circ} \mathrm{C}$, the average air temperature of July is $+19^{\circ} \mathrm{C}$. The absolute maximum temperature is $+38^{\circ} \mathrm{C}$, the absolute minimum is $-37^{\circ} \mathrm{C}$. The frost-free period lasts for 150-175 days. The period with average daily temperatures above $+5^{\circ} \mathrm{C}$ is $195-200$ days, above $10^{\circ} \mathrm{C}-155-160$ days, above $15^{\circ} \mathrm{C}-105-$ 110 days. The amount of air temperatures above $10^{\circ} \mathrm{C}$ is $2460-2580^{\circ} \mathrm{C}$.

The average rainfall is $500-610 \mathrm{~mm}$ per year. During the period with temperatures above $+5^{\circ} \mathrm{C}$, the average rainfall is $400-440 \mathrm{~mm}$, during the period with temperatures above $+10^{\circ} \mathrm{C}-290-340 \mathrm{~mm}$. The maximum rainfall occurs in July (70-85 mm), the minimum - in February $(30 \mathrm{~mm})$. The average snow-cover duration is $100-115$ days. The average of the decade maximum snow depth in winter is $21-22 \mathrm{~cm}$. The average depth of soil freezing is $85 \mathrm{~cm}$. The prevailing wind direction is from the south in winter and from the north-west in summer. The average wind speed is $2-5 \mathrm{~m} / \mathrm{s}$. The relative humidity is $72-77 \%$.

Eastern Polesie has an extensive hydrological network. Sod-weakly and sod-medium podzolic soils prevail in the topsoil. Sandy and sandy loams also occur, sometimes gleyed, often in the complex with sod-gley and marsh soils. Loess "islands" are covered with grey, sometimes dark grey forest soils, among which meadow and saline soils occur on poorly drained lower reaches in the complex with marsh soils. Large areas are occupied by floodplains with alluvial meadow and marsh soils.

Eastern Polesie is situated in the European deciduous forest geobotanical region (zone), the Eastern European province, the Polesie Subprovince. The modern vegetation of Eastern Polesie has undergone considerable transformation. The arable lands cover about $40 \%$ of the total area, wetlands - about $2 \%$, forests $-20-25 \%$. The meadows occupied about $20 \%$ of the area. The main areas of Eastern Polesie are covered with pine and oak-pine forests.

The originality of the landscape structure of Eastern Polesie consists in the fact that along with Polesie-type localities (about $70 \%$ of the explored area) natural complexes become widespread. About $15 \%$ of the landscape shows forest-steppe features. Floodplain natural complexes cover about $10 \%$ of the region's area, areas with eroded grey forest soils and moraine-outwash plains with eroded soils - about $3 \%$, the Predpolesky complex - about $2 \%$.

\section{Material and methods}

The research on the flora and vegetation of Eastern Polesie was carried out in 2002-2016. To determine the range of the $J$. communis population, we used a navigation device eTrex. The ontogenetic stages were determined after Evstigneev and Korotkov (2016). To draw up a schematic map of the species' spread, we used the results of our fieldwork as well as data from the literature (Mulyarchuk, 1962; Fedotov, 2004; Panchenko, 2005) and herbarium materials of M. Kholodny Institute of Botany (Ukraine), F. Skorina State University of Gomel (Belarus), T. Shevchenko National Pedagogical University of Chernihiv (Ukraine), the State Nature Reserve "Bryansk Forest" (Russia). Syntaxa were identified according to Matuszkiewicz (2001), Bulohov and Solomeshch (2003).

\section{Results and discussion}

According to the herbarium of F. Skorina State University of Gomel, there are two known locations of J. сотmunis in the Gomel region, Belarus, Eastern Polesie. There are 54 known locations of the species (Fedotov, 2004) in Nerusso-Desnyanskoye Polesie (Bryansk region, Russia). In the Altuhovo forest district (Bryansk region), J. communis sometimes forms the sparse shrub layer. Other locations are represented by single plants. According to the herbarium collections of M. Kholodny Institute of Botany, T. Shevchenko National Pedagogical University of Chernihiv and literature data (Mulyarchuk, 1962; Panchenko, 2005), there are 8 known sites of the species in the area of Novgorod-Seversky Polesie. The largest sites (in terms of area covered) are in the neighbourhood of the Razlyoty village in the Korop district, the Chernihiv region, and in the "Novovasilyevskoe" forest (Seredino-Buda district, Sumy region, Ukraine). Two known sites of J. communis are located in Chernihiv Polesie, north of the Desna River estuary (pine forest terraces of the Desna and the Dnieper rivers).

We have described some of the already known (Table 1 , relevés $4,8,9$ ) and new locations of $J$. communis (relevés 1-3, 5-7, 10) in Eastern Polesie. 
Table 1. Floristic structure of plant communities with Juniperus communis

\begin{tabular}{|c|c|c|c|c|c|c|c|c|c|c|}
\hline Relevé number & 1 & 2 & 3 & 4 & 5 & 6 & 7 & 8 & 9 & 10 \\
\hline Tree layer cover [\%] & 40 & 35 & 40 & 50 & 35 & 30 & 25 & 30 & 30 & 40 \\
\hline Shrub layer cover [\%] & 5 & 5 & 10 & 25 & 10 & 5 & + & + & + & 40 \\
\hline Herb layer cover [\%] & 20 & 20 & 25 & 45 & 15 & 25 & 10 & 5 & 10 & 60 \\
\hline Mosses cover [\%] & 100 & 65 & 70 & 25 & 70 & 20 & - & - & 15 & - \\
\hline Lichens cover [\%] & - & - & - & - & - & - & 30 & 15 & 30 & - \\
\hline Syntaxon & \multicolumn{5}{|c|}{1} & 2 & \multicolumn{3}{|c|}{3} & 4 \\
\hline \multicolumn{11}{|l|}{ DAss. Peucedano-Pinetum } \\
\hline Convallaria majalis & 1 & . & 1 & + & . & 2 & . & . & + & + \\
\hline Peucedanum oreoselinum & + & + & + & + & + & + & . & . & . & + \\
\hline Polygonatum odoratum & + & + & + & + & + & + & . & . & . & . \\
\hline Pulsatilla patens & . & + & . & . & . & . & . & . & + & . \\
\hline Solidago virgaurea & + & + & + & + & + & . & . & $\cdot$ & $\cdot$ & $\cdot$ \\
\hline \multicolumn{11}{|l|}{ DAss. Veronico incanae-Pinetum } \\
\hline Campanula persicifolia & . & . & . & . & . & + & . & . & . & . \\
\hline Genista tinctoria & . & . & $\cdot$ & $\cdot$ & . & + & . & . & . & . \\
\hline Hieracium umbellatum & + & $\cdot$ & $\cdot$ & . & + & + & . & + & . & $\cdot$ \\
\hline Geranium sanguineum & . & $\cdot$ & $\cdot$ & . & $\cdot$ & + & . & $\cdot$ & $\cdot$ & . \\
\hline Koeleria grandis & . & . & . & . & . & + & . & . & . & . \\
\hline Rubus saxatilis & . & . & . & . & . & + & . & . & . & . \\
\hline Silene nutans & . & $\cdot$ & $\cdot$ & $\cdot$ & $\cdot$ & + & . & $\cdot$ & $\cdot$ & $\cdot$ \\
\hline Veronica incana & . & . & . & . & . & + & . & . & . & . \\
\hline \multicolumn{11}{|l|}{ DAss. Cladonio-Pinetum } \\
\hline Carex ericetorum & . & . & $\cdot$ & . & $\cdot$ & . & + & + & + & \\
\hline Cladina rangiferina & . & . & . & . & . & . & 3 & 3 & 4 & \\
\hline Cladonia uncialis & . & $\cdot$ & $\cdot$ & $\cdot$ & $\cdot$ & . & 1 & $\cdot$ & 2 & \\
\hline Cladonia gracilis & . & . & . & . & . & . & 2 & . & + & \\
\hline Jurinea cyanoides & & . & . & & . & . & + & + & + & . \\
\hline Koeleria glauca & + & + & + & . & . & 1 & 1 & 1 & 1 & . \\
\hline \multicolumn{11}{|l|}{ Species of pine forests on mineral soils } \\
\hline Festuca ovina & . & 1 & . & 1 & . & 1 & 1 & + & 1 & . \\
\hline Juniperus communis & + & + & + & 1 & 3 & + & + & + & + & + \\
\hline Pteridium aquilinum & . & . & $\cdot$ & + & 1 & + & . & . & . & . \\
\hline Luzula pilosa & . & + & $\cdot$ & + & + & + & . & & $\cdot$ & \\
\hline Rumex acetosella & + & $\cdot$ & $\cdot$ & $\cdot$ & $\cdot$ & + & + & + & . & . \\
\hline Sorbus aucuparia & 1 & + & 1 & + & . & + & . & + & . & . \\
\hline \multicolumn{11}{|l|}{ DAss. Querco-Pinetum, species of mixed forests } \\
\hline Asarum europaeum & . & . & . & $\cdot$ & . & . & . & . & . & + \\
\hline Carex brizoides & . & $\cdot$ & $\cdot$ & $\cdot$ & $\cdot$ & · & . & . & $\cdot$ & + \\
\hline Carex sylvatica & . & . & . & . & . & . & . & . & . & + \\
\hline Carpinus betulus (shrub layer and herb layer) & . & $\cdot$ & $\cdot$ & $\cdot$ & $\cdot$ & . & . & . & . & + \\
\hline Corylus avellana & . & . & . & . & . & . & . & . & . & 2 \\
\hline
\end{tabular}




\begin{tabular}{|c|c|c|c|c|c|c|c|c|c|c|}
\hline Relevé number & 1 & 2 & 3 & 4 & 5 & 6 & 7 & 8 & 9 & 10 \\
\hline Euonymus verrucosa & . & . & . & . & . & . & . & . & . & + \\
\hline Melica nutans & . & . & . & . & . & . & . & . & . & + \\
\hline Mycelis muralis & + & . & + & . & . & . & . & . & . & + \\
\hline Stellaria holostea & . & . & . & . & . & . & . & + & . & 4 \\
\hline Quercus robur (tree layer and herb layer) & + & . & + & . & . & . & . & . & . & 2 \\
\hline \multicolumn{11}{|l|}{ ChAll. Dicrano-Pinion } \\
\hline Chimaphila umbellate & + & + & + & + & + & + & . & + & . & + \\
\hline Monotropa hipopitys & + & + & + & + & + & . & + & . & + & + \\
\hline \multicolumn{11}{|l|}{ DO. Cladonio-Vaccinietalia } \\
\hline Arctostaphylos uva-ursi & $\cdot$ & . & $\cdot$ & + & . & . & . & $\cdot$ & . & . \\
\hline \multicolumn{11}{|l|}{ ChO. Cladonio-Vaccinietalia } \\
\hline Pinus sylvestris & 4 & 4 & 4 & 4 & 4 & 4 & 4 & 4 & 4 & 4 \\
\hline Dicranum polysetum & . & + & 1 & 3 & + & . & . & . & 2 & . \\
\hline \multicolumn{11}{|l|}{ ChCl Vaccinio-Piceetea } \\
\hline Dicranum scoparium & + & . & . & . & + & . & . & . & . & . \\
\hline Hylocomium splendens & . & . & 1 & . & + & . & . & . & . & . \\
\hline Lycopodium annotinum & 2 & . & 2 & + & + & . & . & $\cdot$ & . & . \\
\hline Melampyrum pratense & + & . & + & + & . & . & + & 1 & . & . \\
\hline Pleurozium shreberi & 5 & 5 & 5 & 5 & 4 & 3 & . & $\cdot$ & + & . \\
\hline Ptilium crista-castrensis & . & . & + & + & + & . & . & . & . & . \\
\hline Pyrola rotundifolia & + & + & + & $\cdot$ & + & $\cdot$ & . & $\cdot$ & . & . \\
\hline Trientalis europaea & . & + & . & + & + & + & . & . & . & . \\
\hline Vaccinium myrtillus & $\cdot$ & . & $\cdot$ & 2 & $\cdot$ & + & . & + & $\cdot$ & + \\
\hline Vaccinium vitis-idaea & + & + & + & 1 & . & + & + & . & + & + \\
\hline \multicolumn{11}{|l|}{ Other species } \\
\hline \multicolumn{11}{|l|}{ Tree layer } \\
\hline Betula pendula & + & 2 & + & . & 1 & + & . & + & + & + \\
\hline Populus tremula & $\cdot$ & . & $\cdot$ & $\cdot$ & + & + & . & + & $\cdot$ & . \\
\hline \multicolumn{11}{|l|}{ Shrub layer } \\
\hline Frangula alnus & $\cdot$ & 2 & . & 1 & 2 & . & · & $\cdot$ & + & 4 \\
\hline Populus tremula & $\cdot$ & . & . & . & + & + & . & + & . & . \\
\hline Rubus idaeus & $\cdot$ & + & $\cdot$ & + & $\cdot$ & . & . & + & $\cdot$ & + \\
\hline Salix caprea & 1 & + & 1 & $\cdot$ & $\cdot$ & + & . & + & . & . \\
\hline Sambucus racemosa & + & $\cdot$ & + & . & $\cdot$ & . & . & . & $\cdot$ & . \\
\hline \multicolumn{11}{|l|}{ Herb layer } \\
\hline Agrostis tenuis & $\cdot$ & $\cdot$ & $\cdot$ & $\cdot$ & 1 & + & . & . & $\cdot$ & . \\
\hline Agrostis vinealis & $\cdot$ & $\cdot$ & $\cdot$ & $\cdot$ & $\cdot$ & 1 & · & $\cdot$ & $\cdot$ & . \\
\hline Antennaria dioica & $\cdot$ & . & $\cdot$ & + & $\cdot$ & . & . & + & . & . \\
\hline Arenaria saxatilis & $\cdot$ & . & $\cdot$ & . & $\cdot$ & $\cdot$ & . & . & + & . \\
\hline Calamagrostis epigeios & + & 1 & + & 1 & 4 & 2 & + & + & . & + \\
\hline Calamagrostis arundinacea & $\cdot$ & $\cdot$ & $\cdot$ & + & $\cdot$ & 1 & . & . & $\cdot$ & . \\
\hline Chamaecytisus ruthenicus & + & . & + & + & + & 1 & 1 & 1 & + & . \\
\hline
\end{tabular}




\begin{tabular}{|c|c|c|c|c|c|c|c|c|c|c|}
\hline Relevé number & 1 & 2 & 3 & 4 & 5 & 6 & 7 & 8 & 9 & 10 \\
\hline Calluna vulgaris & . & . & . & + & . & . & 1 & . & . & . \\
\hline Carex hirta & . & 1 & . & . & . & 1 & . & . & . & . \\
\hline Clinopodium vulgare & . & . & . & . & + & . & . & . & . & . \\
\hline Dianthus pseudosquarrosus & . & + & . & . & & + & . & . & . & . \\
\hline Dryopteris carthusiana & + & + & + & + & . & + & . & + & . & + \\
\hline Euphorbia cyparisias & . & . & . & . & . & + & . & + & . & . \\
\hline Fragaria vesca & + & . & + & + & . & + & . & . & . & . \\
\hline Galium verum & . & . & . & . & + & 1 & . & . & . & . \\
\hline Galeopsis tetrahit & . & . & . & . & . & . & . & . & . & + \\
\hline Hypericum perforatum & . & . & . & . & . & + & . & + & . & . \\
\hline Jasione montana & . & . & . & . & . & . & + & . & + & . \\
\hline Linaria genistifolia & . & + & . & . & . & $\cdot$ & . & . & . & . \\
\hline Lycopodium clavatum & . & . & . & + & + & . & . & . & & . \\
\hline Maianthemum bifolium & . & . & . & + & + & + & . & + & . & + \\
\hline Molinia caerulea & . & . & . & . & . & + & . & . & . & . \\
\hline Oberna bechen & + & . & . & . & . & . & . & . & . & . \\
\hline Orthilia secunda & . & 1 & 1 & + & + & + & . & . & . & . \\
\hline Oxalis acetosella & . & . & . & . & . & . & . & . & . & + \\
\hline Pilosella officinarum & + & . & + & . & + & + & . & + & . & . \\
\hline Rubus idaeus & . & . & . & . & + & . & . & . & . & . \\
\hline Thymus serpyllum & . & . & . & + & . & 1 & + & + & + & . \\
\hline Veronica chamaedrys & . & + & + & . & . & . & . & . & . & . \\
\hline Vincetoxicum hirundinaria & . & . & . & . & $\cdot$ & . & . & . & + & . \\
\hline Viola tricolor & . & . & . & . & . & + & + & + & . & . \\
\hline Veronica officinalis & + & . & . & . & + & . & . & + & . & . \\
\hline Veronica spicata & . & . & . & . & . & + & + & + & + & . \\
\hline \multicolumn{11}{|l|}{ Mosses } \\
\hline Climacium dendroides & . & 3 & 1 & . & . & . & . & . & . & . \\
\hline Polytrichum commune & 2 & . & + & . & + & + & . & . & . & . \\
\hline Polytrichum juniperinum & 2 & + & 2 & . & + & + & . & . & 1 & . \\
\hline
\end{tabular}

Notes.

Locality of relevés: 1 - 10.07.2016, forest of Gorbachev forestry at Shapiha village (Kozelets district, Chernihiv region, Ukraine); 2 08.04.2015, Mekshunovka forestry, sq. 17 (Repky district, Chernihiv region, Ukraine); 3 - 10.05.2006, Korenevka forestry (Gomel district, Gomel region, Belarus); 4 - 13.07.2006, Altuhovo forestry, sq. 48 (Navlinsk district, Bryansk region, Russia); 5 - 11.09.2007, Klimovo forestry, sq. 117 (between Brahlov village and Solovskoy farm, Klimovo district, Bryansk region, Russia); 6 - 09.08.2006, military forestry, sq. 410, Mizhrichensky regional landscape park (Kozelets district, Chernihiv region, Ukraine.); 7 - 17.04.2016, tract Rudyakovschina, military forestry, sq. 409, Mizhrichensky regional landscape park (Kozelets district, Chernihiv region, Ukraine); 8 - 14.05.2013, tract Novy Lis, at Birine village (Novgorod-Siversky district, Chernihiv region, Ukraine); 9 - 12.07.2016, Holmechy forestry, sq. 17 (Suzemka district, Bryansk region, Russia); 10 - 10.09.2007, Klimovo forestry (at Pokrovskoye village Klimovo district, Bryansk region, Russia).

Plant communities: 1 - Peucedano-Pinetum W. Matuszkiewicz (1962) 1973, 2 - Veronico incanae-Pinetum Bulokhov et Solomeshch 2003, 3 - Cladonio-Pinetum Juraszek 1927, 4 - Querco-Pinetum (W. Matuszkiewicz 1981) J. Matuszkiewicz 1988.

Cover abundance scale: + - less than 1\%, 1-1-5\%, 2-6-12\%, 3-13-25\%, 4-26-50\%; 5 - more then $50 \%$.

Authors of relevés: A. Sliuta (1), S. Kyrienko (2), O. Lukash (3-6, 7, 9, 10), P. Buzunko (8). 
It should be noted that $J$. communis in Eastern Polesie grows mainly in the sub-continental pine forest (Peucedano-Pinetum W. Matuszkiewicz (1962) 1973) (Table 1, description 1-5) and very rarely in pine forests of the association Veronico incanae-Pinetum Bulokhov et Solomeshch 2003. The tree layer of the fresh pine forest is formed by Pinus sylvestris L. with an admixture of Betula pendula Roth. The shrub layer is not abundant and consists of Frangula alnus Mill., Salix caprea L., Sorbus aucuparia L. J. communis is represented by single individuals, which sometimes account for $5-15 \%$ of the total plant cover. The projective cover of the herb layer is $25-45 \%$. It includes typical species (Calamagrostis epigeios (L.) Roth, Convallaria majalis L.) and diagnostic species of the association Peucedano-Pinetum (Peucedanum oreoselinum (L.) Moench and Polygonatum odoratum (Mill.) Druce and others). The projective cover of mosses in the Veronico incanae-Pinetum community is $100 \%$.

The association Peucedano-Pinetum is varied along the geographical gradient. According to the literature data, Bulokhov and Solomeshch (2003) distinguished the Veronico incanae-Pinetum association based on the material from the Bryansk region. In the Chernihiv region, J. communis was found in the Veronico incanae-Pinetum com- munity and described in 2006. The differential species of this association are listed in Table 1 (relevé 6).

The sites of $J$. communis were also found in dry pine woods with the lichen cover, representing the association of Cladonio-Pinetum Juraszek (Table 1, relevés 7-9). The lichen pine forests cover the grounds up to the high sand dunes on the river terraces. They have a sparse tree layer and basically no shrub layer - Juniperus communis is represented by single individuals, and a loose herb layer. Species of southern pine forest and forest steppes occur in the herb layer: Koeleria glauca (Spreng.) DC, Jurinea cyanoides (L.) Reichenb., Chamaecytisus ruthenicus (Fisch. ex Woloszcz.) Klaskova, Thymus serpyllum L., Veronica spicata L., Jasione montana L. The projective cover of Festuca ovina L. is up to 5\%. Lichen species - Cladina rangiferina (L.) Nyl., Cladonia uncialis (L.) Veb., Cladonia gracilis (L.) Willd. - are well represented in the community.

Oak-pine forests representing the Querco-Pinetum association (W. Matuszkiewicz 1981) J. Matuszkiewicz 1988 are typical of Eastern Polesie. J. communis is, however, less common in these communities (Table 1, relevé 10).

Plant communities with $J$. communis in Eastern Polesie are as follows:
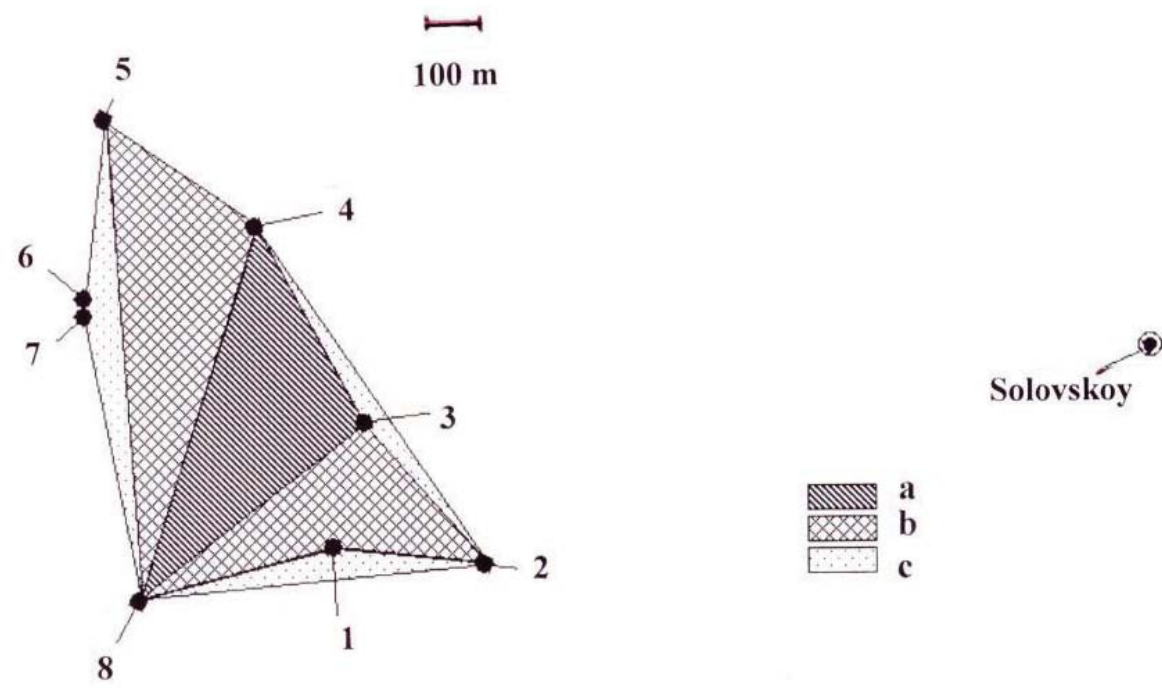

Figure 1. Spatial structure of the Juniperus communis L. population in the Klimovo forest district (between Brahlov village and Solovskoy farm, Klimovo district, Bryansk region, Russia). Coordinates of points: 1 - N 52²2'43.2", E 32॰31'51.0”; 2 - N

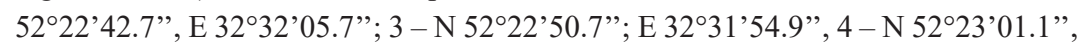

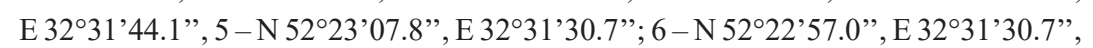

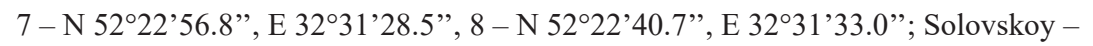
$\mathrm{N} \mathrm{52} 22^{\prime} 54.5^{\prime}$, E $32^{\circ} 33^{\prime} 07.4^{\prime \prime}$; a - plot with the dominance of reproductive middleage individuals (projective cover of $J$. communis 10-20\%), b - plot with the dominance of virginile plants (projective cover of J. communis 5-9\%), c - plot with the dominance of juvenile plants (projective cover of J. communis to $5 \%$ ) 
Class: Vaccinio-Piceetea Br.-Bl. 1939

Order: Cladonio-Vaccinietalia Kielland-Lund 1967

Alliance: Dicrano-Pinion Libbert 1933

Association: Cladonio-Pinetum Juraszek 1927

Association: Peucedano-Pinetum W. Matuszkiewicz (1962) 1973

Association: Veronico incanae-Pinetum Bulokhov et Solomeshch 2003.

The largest population of $J$. communis in Eastern Polesie was studied. It is located in the Klimovo forest district (Table 1, relevé 5) and covers an area of 22 ha. All ontogenetic stages (from seedlings to mature generative plants) in the spectrum of the studied population were represented. We identified three types of plots in the area of the Klimovo forest district, with varying age and projective cover of $J$. communis (Fig. 1). The plot dominated by generative plants (Fig. 1: 1, Fig. 2: I) is a source location from where plants spread in the forest in the northwestern and south-eastern directions. The contribution of virginile plants along these directions becomes smaller compared to other areas (Fig. 1: 2; Fig. 2: II). The role of $J$. communis in a phytocenosis is also reduced along these directions. Peripheral plots of the population (Fig. 1: 3; Fig. 2: III) are characterised by the greatest stability of plantlets and juvenile plants. The population is homeo- static and characterised by an equilateral range of ontogenetic stages with the dominance of virginile plants (Fig. 2: IV).

The schematic map of $J$. communis distribution in Eastern Polesie is presented in Fig. 3. The largest populations in Eastern Polesie (in terms of the area and the number of individuals) occur in the territory of Ukraine (Pridesnyansky physical-geographical district) and Russia (NerussoDesnyansky and Snovsky physical-geographical districts). In Klimovo and Altuhovo forest districts, the outskirts of the Razlyoty village and in the "Novovasilevskoe" tract, $J$. communis grows over a square area of 1-3 ha with a projective cover of $10-20 \%$ in the shrub layer. Specimens of different ages (with the dominance of virginile plants) are present in the populations. Single individuals of the species occur scattered on pine forest terraces of the Desna and the Dnieper rivers. Symptoms of thermal conditions unfavourable for the species are observed here: seedlings and juvenile plants are absent in the localities of $J$. communis, while reproductive individuals show very low seed production. In communities with the thick undergrowth of Frangula alnus, withering of $J$. communis was observed during our study. We determined the southern limit (in Eastern Polesie) of the distribution of communities with the codominance of $J$. communis. It passes through the villages Brahlov-Razlyoty-Ochkino-Navlya.

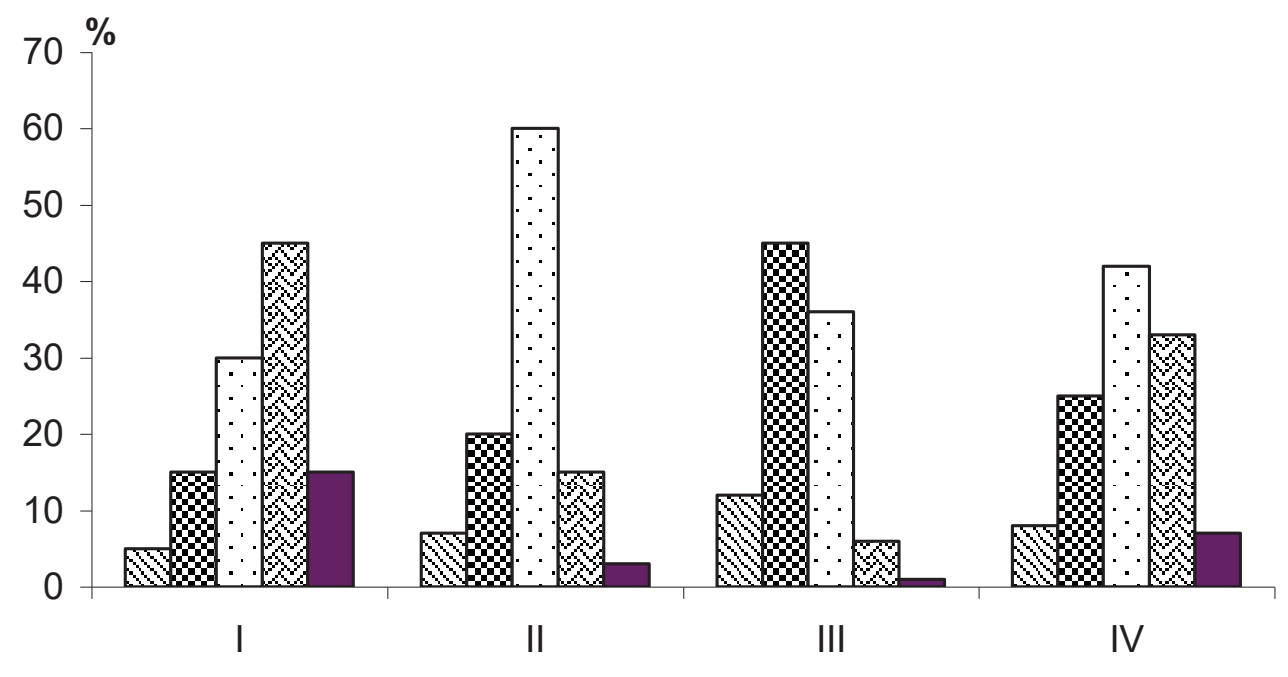

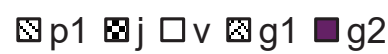

Figure 2. Age-related structure of the Juniperus communis L. population in the Klimovo forest district (between Brahlov village and Solovskoy farm, Klimovo district, Bryansk region, Russia). Explanations: I plot $a$ (as in Fig. 1), II - plot $b$ (as in Fig. 1), III - plot $c$ (as in Fig. 1), IV - the whole population; $\mathrm{p}_{1}$ - seedlings, $\mathrm{j}$ - juvenile individuals, $\mathrm{v}-$ virginile individuals; $\mathrm{g}_{1}-$ young generative individuals, $\mathrm{g}_{2}-$ mature generative individuals 


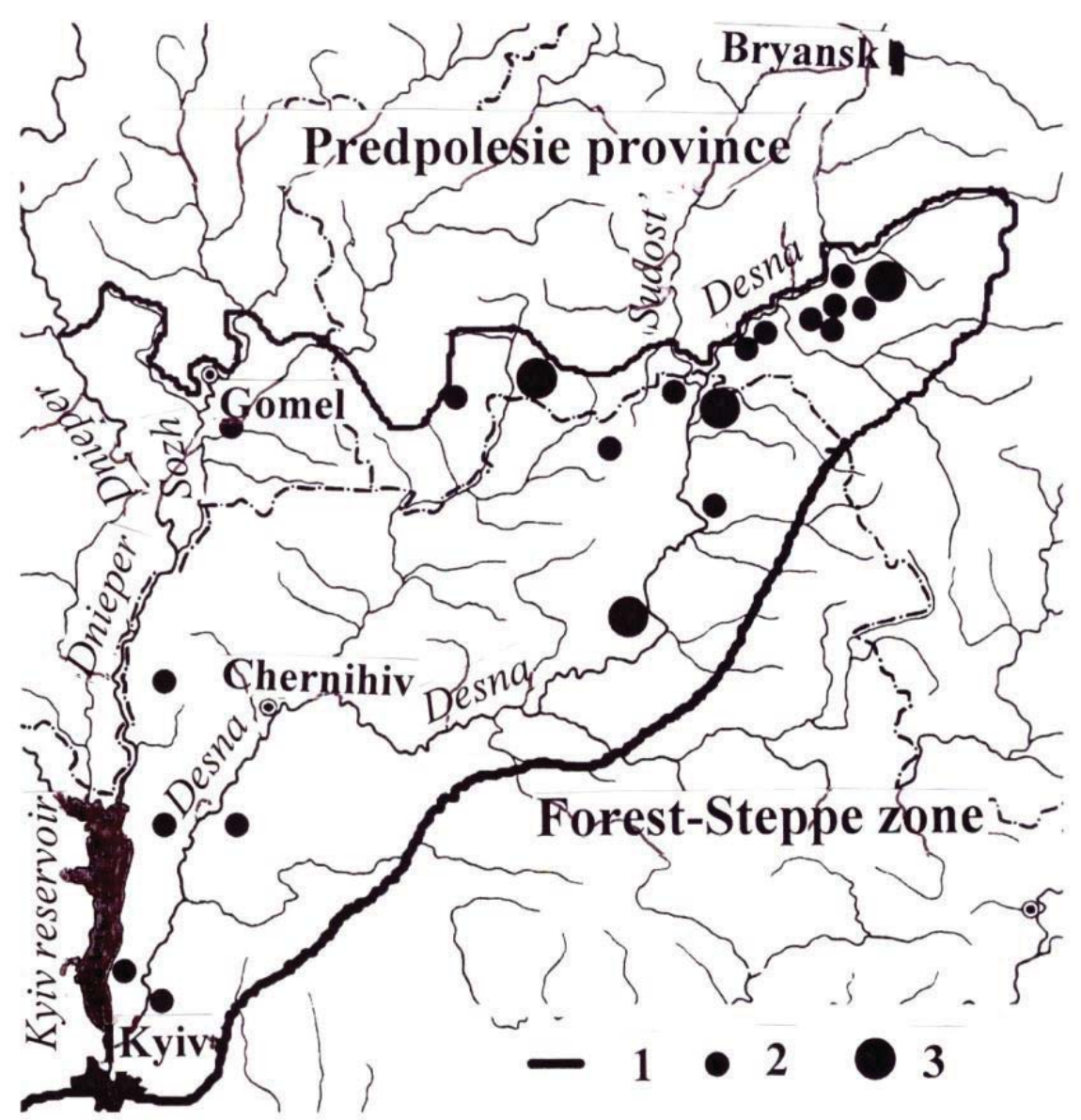

Figure 3. Distribution of Juniperus communis L. in Eastern Polesie; map symbols: 1 - border of Eastern Polesie, 2 - location with single individuals of the species, 3 - locations where the species formed the shrub layer

\section{Conclusions}

$J$. communis habitats in Eastern Polesie are confined to pine forests representing the associations Peucedano- $\mathrm{Pi}$ netum and Cladonio-Pinetum. Small habitats of single individuals of $J$. communis in the communities of Veronico incanae-Pinetum and oak-pine forests of the Querco-Pinetum association were identified.

In Eastern Polesie, the population of J. communis occupies the largest area (22 ha) at the new site located in the Klimovo forest district, between the Brahlov village and the Solovskoy farm, and is characterised by the dynamic equilibrium between the death and replacement of individuals.

The southern limit of communities with the codominance of $J$. communis is defined. In Eastern Polesie, it passes through the villages Brahlov-Razlyoty-Ochkino-Navlya. South of the distribution limit, J. communis occurs sporadically and shows symptoms of unfavourable thermal conditions.

\section{References}

Bulohov A.D. \& Solomeshch A.I., 2003, Syntaxonomy of forests of Russian South Nechernozemie. Publishing house of Brjansk State University, Brjansk: 1-359.

Didukh Ya.P., Pljuta P.G., Protopopova V. V., Yermolenko V. M., Korotchenko I.A. \& Fitsailo T. V., 2000, Ecoflora of Ukraine, Vol. 1: General Part. Lycopodiophyta. Equisetophyta. Polypodiophyta. Pinophyta. Ed. Ya.P. Didukh, Kyiv: 246-247.

Evstigneev O.I. \& Korotkov V.N., 2016, Ontogenetic stages of trees: an overview. Russian Journal of Ecosystem Ecology 1(2): 4-29. doi: 10.21685/2500-0578-1 (2) [http://rjee.ru/rjee-1-2-2016-1]. 
Marinich A.M., 1963, Geomorphology of the southern Polesie. Ed. L.F. Holovniak Publishing house of Kyiv State University, Kyiv: 1-252.

Matuszkiewicz W., 2001, Przewodnik do oznaczania zbiorowisk roślinnych Polski. Wydawnictwo Naukowe PWN, Warszawa: 1-540.

Mulyarchuk S.O., 1962, Distribution of the communitis Juniperus communis L. in the Left-bank Polesie. Ukrainian Botanical Journal 19(6): 97-99.
Panchenko S.M., 2005, Flora of the National Park "Desna-Starogutskiy" and problems of phytodiversity of Novgorod-Siversky Polesie. Ed. Yu.A. Zlobin, University book, Sumy: 1-170.

Fedotov Yu. P., 2004, The Red Book of the Bryansk region. Plants. Mushrooms. Publishing house of Chitaj City, Bryansk: 41-43.

Valyagina-Maljutina E.T., 2001, Trees and shrubs in winter. The determinant of trees and shrubs on the shoots and buds in the leafless state. Publishing house KMK, Moscow: 1-2001. 